\section{Cruise Explores Hydrothermal Vents of the Manus Basin}

A joint Japanese-French program (New STARMER) sampled active hydrothermal sites near the New Britain active subduction zone in the South Pacific from October 16 to November 13,1995 . Using the $R / V$ Yokosuka and the submersible Shinkai 6500 , researchers made a number of surprising findings about magmatic, tectonic, and hydrothermal activity at the central and northeastem ridges of the Manus $\mathrm{Ba}$ sin spreading system. Fifteen dives by the submersible revealed a spectrum of hydrothermal processes, ranging from shimmering waters to black smokers. For the first time, highly acidic fluids rich in $\mathrm{H}_{2} \mathrm{~S}$ and low in temperature $\left(87-118^{\circ} \mathrm{C}\right)$ were sampled in the eastern part of the Manus Basin.

\section{Central Ridge/Manus Spreading Center}

Two diving sites were selected at the central ridge/manus spreading center (MSC). The Vienna Woods site (see Figure 1) is an important field of active and fossil hydrothermal chimneys about $300 \mathrm{~m}$ in diameter, located on a magmatic mound made of pillows and lava tubes at 2500 -m-depth in the axial graben. It lies on a fault bounding to the southeast of the neovolcanic ridge [Craig and Poreda, 1987; Tufar, 1990; Lisitzin et al, 1990]. At this site researchers found large hydrothermal plumes of $\mathrm{CH}_{4}$ of ${ }^{3} \mathrm{He}$ and an area of lobated lava, and pillows near the site shows intense fissuring.

[Craig and Poreda, 1987].

The main chimneys explored at the Vienna Woods site, which are $10-15 \mathrm{~m}$ high and lie atop a sulfide mound, expel $285-300^{\circ} \mathrm{C}$ shimmering fluid. These chimneys are large and composed of sulfide, oxides, and silica. Another smaller type of chimney is found on the seafloor; they are just 1-2 $\mathrm{m}$ high and composed of anhydrite.

The second site explored is Munkalin volcano, an axial volcano in the southern part of the central ridge that was recently emplaced in a system of conjugated fractures. It lies at 1942-m depth, and its axis runs in the direction of the Wuillaumez FZ. This area contains outcropping rocks and lava tubes organized in a succession of very recent flows. Although a large $\mathrm{CH}_{4}$ plume was measured at Munkalin volcano [Craig and Poreda, 1987], no hydrothermal venting was found.

\section{Southeastern Ridge}

The southeastem ridge (SER) is a complex intra-arc extensional domain [Martinez and Taylor, 1996]. Two sites here were chosen for exploration, the PACMANUS (Papua New Guinea, Australia, Canada Joint Program in Manus Basin) area to the west and the DESMOS (Deep Sea Monitoring Japanese System) area to the east. The PACMANUS site, which was discovered during the Papatua Expedition [Craig and Poreda, 1987], is located on Pual ridge, a northeast trending, 1700-2200-m-deep linear massive. The top of the Pual ridge is dotted by circular or elongated seamounts a few hundred meters wide and $50 \mathrm{~m}$ high.

Dive observations and sampling show that the seamounts consist of intrusions of dacitic bodies through an andesitic substratum. Active hydrothermal vents lie on the north-south faults separating the seamounts at the PACMANUS site (Figure 1). Here five active vents were explored; two release shimmering water (temperature $45^{\circ} \mathrm{C}-63^{\circ} \mathrm{C}$ ) and the others are sulfides chimneys that expel high-temperature, acidic black fluids.

At the DESMOS site, a caldera about $1.5-\mathrm{km}$ in diameter and $300 \mathrm{~m}$ deep, a new type of hydrothermal venting characterized by a sulfuric acid-rich hydrothermal fluid was found. $\mathrm{Hy}$ drothermal deposits [Both et al., 1986] and methane, manganese, alumina, and $\mathrm{pH}$ anomalies in the water column were reported by Craig and Poreda [1987] and Gamo et al. [1993]. The caldera is cut through a thick layer of lava flows, essentially lava tubes and small pillows, which preliminary onboard analysis indicates are andesitic. The faulted walls of the caldera are cut through the lava tube section and are covered with alteration products such as silica, pyrite and elemental sulfur. On the northwestern flank of the caldera an active hydrothermal area emits low-temperature shimmering fluids associated with sulfides, oxides,

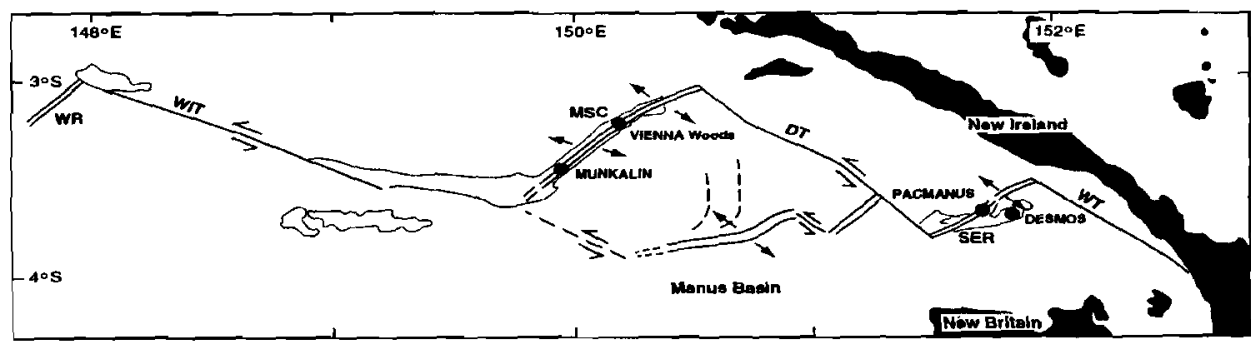

Fig. 1. Sketch of the Manus Basin spreading system [modified after Martinez and Taylor, 1996]. The sites explored are indicated by dark circles. MSC, Manus Spreading Center; SER, Southeastem Ridge; WR, Westem Ridge; WTT, Wuillaumez Transform Fault; DT, Djaul Transform Fault; WT, Weitin Transform Fault.

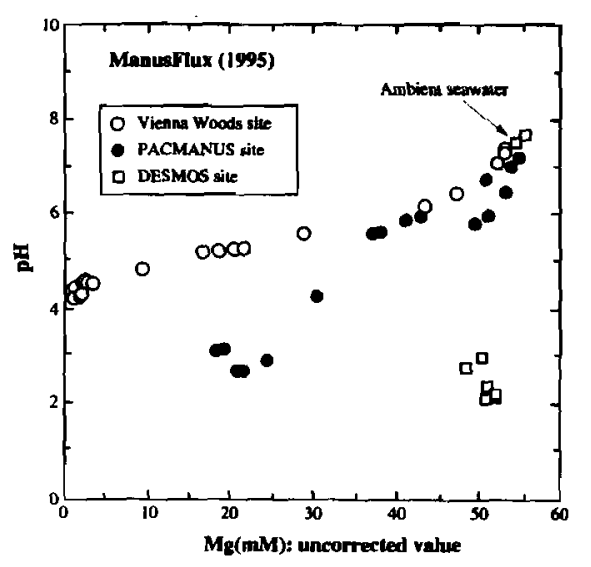

Fig. 2. Values of $p H$ and $M g$ for fluids collected at Vienna Woods, PACMANUS, and DESMOS hydrothermal sites during the cruise.

and bacterial mats. On the eastern side of this hydrothermal zone, a robust vent was sampled on an east-west fault cutting the northwestern edge of the caldera. White fluids from fissures in the andesitic pillows are expelled from this vent.

\section{Water Sampling}

At the three active hydrothermal sites (Figure 2) in situ water samples were taken at 15 vents and up to 60 fluid samples were taken from ambient bottom seawater, plumes, and other hydrothermal features. At the Vienna Woods hydrothermal field, fluids were high in temperature (near $300^{\circ} \mathrm{C}$ ) and $\mathrm{pH}(4.0$ to 4.5$)$, low in $\mathrm{H}_{2} \mathrm{~S}$ (less than $2.0 \mathrm{mmol} / \mathrm{kg}$ ), and high in silica (14-16 mmol/kg). At the PACMANUS site, hydrothermal fluids were a little lower in temperature $\left(240-260^{\circ} \mathrm{C}\right)$, $\mathrm{pH}$ was between 2.6 and $3.1, \mathrm{H}_{2} \mathrm{~S}$ content was between 3.5 and 4.0 $\mathrm{mmol} / \mathrm{kg}$, and silica content was over 10 $\mathrm{mmol} / \mathrm{kg}$.

At the DESMOS hydrothermal field, highly acidic fluids are expelled in great quantity. In sharp contrast to the PACMANUS and Vienna Woods sites, the fluids at DEMOS are relatively low in temperature $\left(87^{\circ} \mathrm{C}-118^{\circ} \mathrm{C}\right)$, with low $\mathrm{pH}$ (around 2), $\mathrm{H}_{2} \mathrm{~S}$ content up to $9.6 \mathrm{mmol} / \mathrm{kg}$, and silica from $3-6 \mathrm{mmol} / \mathrm{kg}$.

The sampled rocks illustrate the peculiar geodynamics of the whole area, particularly near the arc: there are mid-ocean ridge basalts on the north of the central ridge, andesitic basalts on the Munkalin volcano, and acidic (dacite) rocks on the southeastem ridge. This difference in rock composition is possibly one of the parameters that could explain the variability of fluids at the sites explored. Hydrothermal sites observed range from low-temperature shimmering waters to hightemperature black-smokers.

Acknowledgments: We thank Brian Taylor for providing maps and documents for the Manusflux cruise.-Jean-Marie Auzende, IFRE$M E R / C B$, Plouzane, France; now at IFREMER/Del. Cal., Nouméa, Nouvelle 
Calédonie; Tetsuro Urabe, Geological Survey of Japan, Tsukuba, Ibaraki, Japan; and Scientific Party (Ray Binns, Jean-Luc Charlou, Kaul Gena, Toshitaka Gamo, Katell Henny, Osamu Matsubayashi, Takeshi Matsumoto, Roger Moss, Jiro Naka, Yoshiharu Nagaya, Kei Okamura and Etienne Ruellan)

\section{References}

Both, R., K. Crook, B. Taylor, S. Brogan, B.

Chappell, E. Frankel, L. Lui, J. Sinton, and

D. Tiffin, Hydrothermal chimneys and associ- ated fauna in the Manus back-arc basin, Papua New Guinea, Eos, Trans AGU, 67, 489,1986

Craig, $H_{\text {. }}$ and R. Poreda, Studies of methane and helium in hydrothermal vent plumes, spreading axis basalts, and volcanic island lavas and gases in Southwest Pacific marginal basins, Papatua cruise, Scripps Inst. Oceanogr., 87, 80, 1987.

Gamo, T., H. Sakai, J. Ishibashi, E.

Nakayama, K. Ishiki, H. Matsura, K. Shi-

tashima, K. Takeuchi, and S. Ohta, Hy-

drothermal plumes in the eastern Manus

Basin, Bismarck Sea- $\mathrm{CH}_{4}, \mathrm{Mn}, \mathrm{Al}$ and $\mathrm{pH}$ anomalies, Deep Sea Res., 40, 2335, 1993.
Lisitzin et al., Manus Basin PNG, Operations of RV Akademik Mstislav Keldysh, Cruise Rep., 252 pp., 1990

Martinez, F., and B. Taylor, Fast backarc spreading, rifting and microplate rotation between transform faults in the Manus Basin, Bismarck Sea, Mar. Geophys. Res., Spec. Iss., edited by J.-M.Auzende and J.-Y.Collot, 18, 1-3, 1996.

Tufar, W., Modern hydrothermal activity, formation of complex massive sulfide deposits and associated vent communities in the Manus back-arc basin (Bismark Sea, Papua New Guinea), Mitt. Osterr. Geol. Ges., 82 $183,1990$. 